\title{
PENGARUH REKRUITMEN DAN SELEKSI TERHADAP PRODUKTIVITAS KERJA GURU PADA YAYASAN PONDOK INDAH DON BOSCO JAKARTA SELATAN
}

\author{
Ading Sunarto, ${ }^{1}$ Diva Aprianda ${ }^{2}$ \\ Fakultas Ekonomi, Universitas Pamulang \\ Email: dosen02153@unpam.ac.id¹, divaaprianda14@gmail.com²
}

\begin{abstract}
Purpose. This study aims to determine the effect of recruitment and selection on teacher productivity at the Pondok Indah Don Bosco Foundation, South Jakarta.

Methods. The research method used in this study is an associative method and data collection using a questionnaire technique. This study used a saturated sample with 64 respondents. The method of data analysis was the validity test, the reliability test, the multiple linear regression equation, the correlation coefficient, the coefficient of determination, and the significance test.
\end{abstract}

Findings. The Effect of Recruitment and Selection on Teacher Work Productivity at the Pondok Indah Don Bosco Foundation shows that, in the correlation coefficient test results, the coefficient value of 0.535 is in the interpretation range of $0.400-0.599$, so it can be concluded that the variable recruitment (X1) and selection (X2) moderate level of relationship strength to teacher work productivity (Y). The coefficient of determination obtained by the coefficient of determination (R-square) is 0.254 , it can be concluded that recruitment (X1) and selection (X2) have an influence contribution of 25.4\% on teacher work productivity $(Y)$ and $74.6 \%$ of the factors. others who were not examined in this study. The results of simple linear regression analysis obtained the regression equation, namely $Y=$ $21.041+0.121 \times 1+0.385 \times 2$. It can be concluded that recruitment and selection are in line with the teacher work productivity variable, so it can be concluded that recruitment and selection have a positive effect on teacher work productivity at the Pondok Indah Don Bosco Foundation. Based on the results of the $F$ test, there is a positive and significant effect of variable recruitment (X1) and Selection (X2) on teacher work productivity (Y) at the Pondok Indah Don Bosco Foundation, it can be seen from the value of F count> F table or (8.171> 3.19) This is also reinforced by the probability significance value of $0.001<0.05$.

Implication. Foundations need to pay more attention to a good recruitment system to get the employees needed if they are going to recruit from external sources, foundations and foundations also need to motivate their employees more to create confidence in doing a job.

Keywords. Recruitment, Selection and Productivity.

\begin{abstract}
ABSTRAK
Tujuan. Penelitian ini bertujuan untuk mengetahui pengaruh rekruitmen dan seleksi terhadap produktivitas guru pada Yayasan Pondok Indah Don Bosco Jakarta Selatan.

Metode. Metode penelitian yang dipergunakan dalam penelitian ini adalah metode asosiatif dan pengumpulan data dengan teknik kuesioner. Penelitian ini menggunakan sampel jenuh dengan responden sebanyak 64. Metode analisis data dengan uji validitas, uji
\end{abstract}


reliabilitas, persamaan regresi linier berganda, koefisien kolerasi, koefisien determinasi, dan uji signifikansi.

Hasil. Pengaruh Rekrutmen dan Seleksi Terhadap Produktivitas Kerja Guru pada Yayasan Pondok indah Don Bosco menunjukan bahwa, pada hasil uji koefisien korelasi diperoleh niali koefisien sebesar 0,535 berada pada rentang interpretasi 0,400 - 0,599, maka dapat disimpulkan bahwa variabel rekrutmen (X1) dan seleksi (X2) memiliki tingkat kekuatan hubungan yang sedang terhadap produktivitas kerja guru (Y). koefisien determinasi yang diperoleh nilai koefisien determinasi (R-square) sebesar 0,254, maka dapat disimpulkan bahwa rekrutmen (X1) dan seleksi (X2) memiliki kontribusi pengaruh sebesar $25,4 \%$ terhadap produktivitas kerja guru (Y) dan 74,6\% dari faktor lain yang tidak diteliti pada penelitian ini. Hasil analisis regresi linier sed erhana memperoleh persamaan regresinya yaitu $\mathrm{Y}=21,041+0,121 \times 1+0,385 \times 2$. Hal tersebut dapat disimpulkan bahwa rekrutmen dan seleksi searah dengan variabel produktivitas kerja guru, maka dapat disimpulkan bahwa rekrutmen dan seleksi berpengaruh positif terhadap produktivitas kerja guru pada Yayasan Pondok Indah Don Bosco. Berdasarkan hasil uji F terdapat pengaruh yang positif dan signifikan variabel rekrutmen (X1) dan Seleksi (X2) terhadap produktivitas kerja guru (Y) pada Yayasan Pondok Indah Don Bosco, dapat dilihat dari nilai $\mathrm{F}$ hitung $>\mathrm{F}$ tabel atau $(8,171>3,19)$ hal ini juga diperkuat dengan nilai probability signifikans sebesar $0,001<0,05$.

Implikasi. Yayasan perlu lebih memperhatikan sistem rekrutmen yang baik untuk mendapatkan karyawan yang dibutuhkan jika akan merekrut dari sumber eksternal yayasan serta yayasan juga perlu lebih memotivasi karyawan-karyawan nya untuk menciptakan rasa percaya diri dalam melakukan suatu pekerjaan.

Kata Kunci. Rekruitmen, Seleksi dan Produktivitas.

\section{Pendahuluan}

Di era globalisasi dewasa ini, kemajuan suatu bangsa sangat ditentukan oleh kualitas sumber daya manusia. Kualitas sumber daya manusia bergantung pada kualitas pendidikan. Peran pendidikan sangat lah penting untuk menciptakan masyarakat yag cerdas, damai, terbuka, dan demokratis. Oleh karena itu, pembaruan pendidikan harus selalu dilakukan untuk meningkatkan kualitas pendidikan suatu bangsa. Kemajuan bangsa indonesia hanya dapat dicapai melalui penataan pendidikan yang baik. Upaya peningkatan mutu pendidikan diharapkan dapat menaikan harkat dan martabat manusia indonesia.

Permasalahan pendidikan nasional yang muncul dan sedang dihadapi oleh bangsa indonesia adalah rendahnya mutu pendidikan pada setiap jenjang. Sementara berbagai usaha telah dilakukan dalam meningkatkan mutu pendidikan nasional, antara lain melalui berbagai pelatihan dan peningkatan kompetensi pendidik, perbaikan sarana prasarana pendidikan, dan peningkatan mutu manajemen sekolah. Berbicara mengenai sumber daya manusia, sebenarnya dapat dilihat dari dua aspek, yakni aspek kuantitas dan kualitas. Aspek kuantitas berkaitan dengan jumlah sumber daya manusia itu sendiri. Sedangkan aspek kualitas berkaitan dengan mutu sumber daya manusia tersebut yang didalamnya terdapat kemampuan baik fisik maupun non fisik.

Melihat peran tenaga pendidik dan kependidikan begitu penting maka perlu adanya rekrutmen (penarikan) dan seleksi (pemilihan) yang bisa menghasilkan calon-calon tenaga pendidik yang profesional. Rekrutmen pendidik adalah seperangkat kegiatan dan proses yang dipergunakan untuk memperoleh sejumlah orang yang bermutu sehingga orang dan sekolah dapat saling menyeleksi berdasarkan kepentingan terbaik masing-masing dalam jangka panjang maupun jangka pendek. Dengan pelaksanaan rekrutmen yang baik diharapkan sekolah mendapat tenaga pendidik yang sesuai dengan kualifikasi yang ditetapkan sekolah, karena di dalam keberlangsungan kegiatan sekolah unsur manusia merupakan unsur yang sangat penting, karena kelancaran jalannya pelaksanaan program sekolah sangat ditentukan 
oleh orang-orang yang terlibat di dalamnya. Bagaimanapun lengkap dan modernnya fasilitas gedung, perlengkapan, alat kerja, metode dan dukungan masyarakat, akan tetapi apabila orang-orang yang ada di dalamnya kurang berkompeten terhadap setiap tugas yang dibebannya, maka akan sangat sulit dalam mencapai tujuan pendidikan yang diharapkan.

Salah satu permasalahan yang sering terjadi di dalam rekrutmen dan seleksi tenaga pendidik dan kependidikan yaitu masalah persyaratan-persyaratan yang harus di lengkapi oleh calon tenaga kerja dan juga bersifat subjektif yang artinya umum nya banyak calon karyawan yang dipilih tersebut memiliki hubungan kekerabatan yang erat dengan karyawan yang sudah lama bekerja, yang pada akhirnya tidak mengikuti peraturan-peraturan persyaratan-persyaratan khusus atau yang sudah ditetapkan oleh pemerintah yang pada akhirnya mempengaruhi produktivitas kerja karyawan nya baik yang sudah lama bekerja atau pun yang baru saja mencalonkan sebagai tenaga kerja.

Pelaksanaan rekrutmen dan seleksi merupakan tugas yang sangat penting, krusial dan membutuhkan tanggung jawab yang besar. Hal ini karena kualitas sumber daya manusia yang akan digunakan yayasan sangat tergantung bagaimana prosedur rekrutmen dan seleksi dilaksanakan.Pada tahun 2017 dapat diketahui data dengan penilaian baik yaitu 75\%. Pada tahun 2018 yaitu menjadi 60\%, dan pada tahun 2019 yaitu 55\%. Jadi kesimpulannya para karyawan bisa bekerja dengan baik dan berkualitas dengan adanya dorongan dari atasan untuk tetap bekerja sesuai prosedur perusahaan. Dan apabila karyawan bekerja dengan daya pendorong dari atasan mungkin karyawan akan merasa bahwa dirinya sangat penting bagi perusahaan karena karyawan bukan hanya pekerja tapi juga sebagai asset perusahaan agar perusahaan dapat lebih berkembang dan bisa lebih maju. Dan untuk karyawan pun harus memiliki kerelaan dalam melaksanakan pekerjaannya.

Berdasarkan hasil penelitian, permasalahan yang terjadi di Yayasan Pondok Indah Don Bosco yaitu sistem rekrutmen dan seleksi pada yayasan ini tidak menerapkan persyaratan persyaratan khusus bagi calon karyawan nya yang dimana hanya berdasarkan persyaratan persyaratan umum dan juga bersifat subjektif dalam memilih atau menerima karyawan yang dimana dapat mempengaruhi produktivitas kerja karyawan yang nyatanya menunjukan hasil dalam tiga tahun terakhir ternyata kurang maksimal dan belum tepat dalam merekrut dan menseleksi karyawan. Dengan demikian dapat di simpulkan bahwa pentingnya produktivitas terhadap kelangsungan tujuan perusahaan dengan saling memberikan timbal balik antara karyawan dengan perusahaan. Banyak akibat yang merugikan suatu perusahaan yang di sebabkan karyawan tidak memiliki produktivitas yang tinggi akibatnya dapat terjadi berbagai bentuk tindakan atau perbuatan yang merugikan perusahaan, sebagai contoh hasil kerja yang tidak memenuhi syarat-syarat yang di tetapkan, dan tidak terpenuhi target yang di tetapkan perusahaan.

Berkaitan dengan hal tersebut, maka setiap organisasi maupun perusahaan akan selalu berusaha untuk meningkatkan produktivitas kerja karyawan, dengan harapan apa yang menjadi tujuan organisasi akan tercapai. Berbagai cara akan di tempuh dalam peningkatan produktivitas karyawan. Oleh sebab itu penelitian ini dilakukan untuk meneliti lebih lanjut tentang "Pengaruh Rekruitmen dan Seleksi Terhadap Produktivitas Guru Yayasan ondok Indah Don Bosco Jakarta Selatan".

\section{Kajian Pustaka dan Hipotesis}

Rekruitmen. Rekrutmen adalah proses mendapatkan sejumlah calon tenaga kerja yang kualifaid untuk jabatan / pekerjaan tertentu dalam suatu organisasi atau perusahaan. Menurut Simamora (2014: 170) "rekrutmen adalah serangkaian aktivitas mencari dan memikat pelamar kerja dengan motivasi, kemampuan, keahlian dan pengetahuan yang diperlukan untuk menutupi kekurangan yang diidentifikasi dalam perencanaan karyawan".

$\mathbf{H}_{1}$. Rekruitmen berpengaruh signifikan terhadap produktivitas karyawan 
Seleksi. Menurut Marwansyah (2014: 128) " seleksi adalah proses yang digunakan oleh sebuah organisasi untuk memilih dari sekumpulan pelamar, orang atau orang - orang yang paling baik memenuhi kriteria seleksi untuk posisi yang tersedia dengan mempertimbangkan kondisi lingkungan saat ini". Menurut Siagian (2015) "apabila sekelompok pelamar sudah diperoleh melalui berbagai kegiatan rekrutmen proses selanjutnya yaitu seleksi, seleksi proses yang terdiri dari berbagai langkah spesifik yang diambil untuk memutuskan pelamar mana yang akan diterima dan pelamar mana yang ditolal".

$\mathbf{H}_{2}$. Seleksi berpengaruh signifikan terhadap produktivitas karyawan

Produktivitas. Secara teknis produktivitas merupakan perbandingan antara hasil yang dicapai dengan pasar tenaga kerja persatuan waktu dan sebagai tolak ukur jika ekspansi dan aktivitas dari sikap sumber yang digunakan selama produktivitas berlangsung dengan membandingkan jumlah yang dihasilkan dengan setiap sumber yang digunakan. Menurut Sondang P Siagian (2012: 15) "produktivitas kerja adalah kemampuan memperoleh manfaat sebesar-besarnya dari sarana dan prasarana yang tersedia dengan menghasilkan output yang optimal, kalau mungkin yang maksimal".

$\mathbf{H}_{3}$. Motivasi dan Kompensasi berpengaruh signifikan terhadap produktivitas karyawan

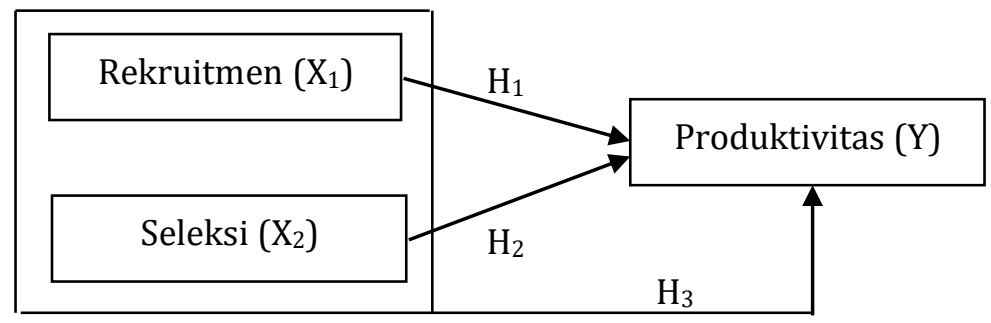

\section{Gambar 1. Model Penelitian}

\section{Metode Penelitian}

Jenis penelitian ini adalah asosiatif, menurut Sugiyono (2012:44) yaitu "Penelitian yang bertujuan untuk mengetahui pengaruh atau hubungan antara dua variabel atau lebih". Dengan demikian penelitian asosiatif ini dapat dibangun suatu teori yang berfungsi untuk menjelaskan, meramalkan dan mengontrol suatu gejala. Dalam penelitian populasinya adalah guru di Yayasan Pondok Indah Don Bosco Jakarta Selatan. Sementara sampel yang digunakan adalah seluruh guru di Yayasan Pondok Indah Don Bosco Jakarta Selatan yang berjumlah 64 guru.

\section{Uji Instrumen Penelitian}

Dalam suatu penelitian, data mempunyai kedudukan yang sangat penting. Hal ini dikarenakan data merupakan penggambaran variabel yang diteliti dan berfungsi sebagai alat pembuktian hipotesis. Valid atau tidaknya data sangat menentukan kualitas dari data tersebut. Hal ini tergantung instrumen yang digunakan apakah sudah memenuhi asas validitas dan reliabilitas. Adapun dalam pengujian instrumen ini digunakan 2 (dua) pengujian yaitu validitas dan reliabilitas.

\section{Uji Asumsi Klasik}

Uji asumsi klasik digunakan untuk mengetahui ketepatan sebuah data. Menurut Santoso (2015:342) berpendapat "Sebuah model regresi akan digunakan untuk melakukan peramalan sebuah model yang baik adalah model dengan kesalahan peramalan yang seminimal mungkin. Karena itu, sebuah model sebelum digunakan seharusnya memenuhi beberapa asumsi, yang biasa disebut asumsi klasik". Dalam penelitian ini uji asumsi klasik yang 
digunakan: Uji Normalitas, Uji Multikolinearitas, Uji Autokorelasi, dan Uji Heterokedastisitas.

\section{Analisis Kuantitatif}

Analisis kuantitatif adalah penelitian untuk menilai kondisi dari nilai pengaruh, dan signifikansi pengaruh tersebut. Dalam penelitian ini analisis kuantitatif yang digunakan: Analisis Regresi Linier Sederhana, Linier Berganda, Analisis Koefisien Korelasi, Analisis Koefisien Determinasi, Pengujian Hipotesis.

\section{Hasil Penelitian dan Pembahasan Uji Validitas Instrumen}

Tabel 1. Hasil Uji Validitas Variabel Rekruitmen $\left(\mathrm{X}_{1}\right)$

\begin{tabular}{|c|c|c|c|}
\hline Pernyataan & r hitung & r tabel & Hasil Uji \\
\hline Pernyataan 1 & 0,467 & 0,271 & Valid \\
\hline Pernyataan 2 & 0,273 & 0,271 & Valid \\
\hline Pernyataan 3 & 0,425 & 0,271 & Valid \\
\hline Pernyataan 4 & 0,499 & 0,271 & Valid \\
\hline Pernyataan 5 & 0,498 & 0,271 & Valid \\
\hline Pernyataan 6 & 0,682 & 0,271 & Valid \\
\hline Pernyataan 7 & 0,407 & 0,271 & Valid \\
\hline Pernyataan 8 & 0,493 & 0,271 & Valid \\
\hline Pernyataan 9 & 0,387 & 0,271 & Valid \\
\hline
\end{tabular}

Sumber : Data diolah (2020)

Tabel 2. Hasil Uji Validitas Variabel Seleksi $\left(\mathrm{X}_{2}\right)$

\begin{tabular}{|c|c|c|c|}
\hline Pernyataan & r hitung & r tabel & Hasil Uji \\
\hline Pernyataan 1 & 0,683 & 0,271 & Valid \\
\hline Pernyataan 2 & 0,428 & 0,271 & Valid \\
\hline Pernyataan 3 & 0,536 & 0,271 & Valid \\
\hline Pernyataan 4 & 0,341 & 0,271 & Valid \\
\hline Pernyataan 5 & 0,361 & 0,271 & Valid \\
\hline Pernyataan 6 & 0,496 & 0,271 & Valid \\
\hline Pernyataan 7 & 0,589 & 0,271 & Valid \\
\hline Pernyataan 8 & 0,452 & 0,271 & Valid \\
\hline Pernyataan 9 & 0,405 & 0,271 & Valid \\
\hline
\end{tabular}

Sumber : Data diolah (2020)

Tabel 3. Hasil Uji Validitas Variabel Produktivitas (Y)

\begin{tabular}{|c|c|c|c|}
\hline Pernyataan Y & r hitung & r tabel & Hasil Uji \\
\hline Pernyataan 1 & 0,671 & 0,271 & Valid \\
\hline Pernyataan 2 & 0,711 & 0,271 & Valid \\
\hline Pernyataan 3 & 0,504 & 0,271 & Valid \\
\hline Pernyataan 4 & 0,613 & 0,271 & Valid \\
\hline Pernyataan 5 & 0,467 & 0,271 & Valid \\
\hline Pernyataan 6 & 0,740 & 0,271 & Valid \\
\hline Pernyataan 7 & 0,464 & 0,271 & Valid \\
\hline Pernyataan 8 & 0,641 & 0,271 & Valid \\
\hline Pernyataan 9 & 0,584 & 0,271 & Valid \\
\hline
\end{tabular}

Sumber : Data diolah (2020) 
Berdasarkan data tabel di atas, variabel $X_{1}, X_{2}$ dan $Y$ diperoleh nilai $r$ hitung $>r$ tabel (0.271), dengan demikian maka semua item kuesioner dinyatakan valid. Untuk itu kuesioner yang digunakan layak untuk diolah sebagai data penelitian.

\section{Uji Reliabilitas Instrumen}

Tabel 4. Hasil Uji Reliabilitas Variabel Independen dan Dependen

\begin{tabular}{|c|c|c|c|}
\hline Variabel & Cronbatch Alpha & $\begin{array}{c}\text { Standar Cronbatch } \\
\text { Alpha }\end{array}$ & Keputusan \\
\hline Rekruitmen (X1) & 0,670 & 0,273 & Reliabel \\
\hline Seleksi (X2) & 0,653 & 0,273 & Reliabel \\
\hline Produktivitas (Y) & 0,790 & 0,273 & Reliabel \\
\hline
\end{tabular}

Sumber : Data diolah (2020)

Berdasarkan hasil pengujian pada tabel di atas, menunjukkan bahwa variabel rekruitmen $\left(\mathrm{X}_{1}\right)$, seleksi $\left(\mathrm{X}_{2}\right)$ dan produktivitas $(\mathrm{Y})$ dinyatakan reliabel, hal itu dibuktikan dengan masing-masing variabel memiliki nilai Chronbath Alpha lebih besar dari 0,273.

\section{Pengujian Asumsi Klasik (Uji Prasyarat Data)}

\section{Uji Normalitas}

Tabel 5. Hasil Uji Normalitas Dengan Kolmogorov-Smirnov Test One-Sample Kolmogorov-Smirnov Test

\begin{tabular}{|ll|r|}
\hline & & $\begin{array}{r}\text { Unstandardized } \\
\text { Residual }\end{array}$ \\
\hline $\mathrm{N}$ & Mean & 51 \\
Normal Parameters ${ }^{\mathrm{a}, \mathrm{b}}$ & Std. & .0000000 \\
& Deviation & 269.387 .325 \\
& Absolute & .092 \\
Most Extreme Differences & Positive & .092 \\
& Negative & -.054 \\
Test Statistic & & .092 \\
Asymp. Sig. (2-tailed) & & $.200 \mathrm{c,d}$ \\
\hline
\end{tabular}

Sumber : Data diolah (2020)

Berdasarkan hasil pengujian pada tabel di atas, diperoleh nilai signifikansi $\alpha=0,092$ dimana nilai tersebut lebih besar dari nilai $\alpha=0,050$ atau $(0,092>0,050)$. Dengan demikian maka asumsi distribusi persamaan pada uji ini adalah normal.

\section{Uji Multikolinearitas}

Tabel 6. Hasil Pengujian Multikolinearitas Dengan Collinearity Statistic Produktivitas karyawan Sebagai Variabel Dependen

\begin{tabular}{|c|c|c|}
\hline \multirow{2}{*}{ Variabel } & \multicolumn{2}{|c|}{ Colinerity Statistics } \\
\cline { 2 - 3 } & Tolerance & VIF \\
\hline Rekruitmen (X1) & 0.667 & 1.499 \\
\hline Seleksi (X2) & 0.667 & 1.499 \\
\hline
\end{tabular}

Sumber : data output yang diolah, 2020

Berdasarkan hasil pengujian multikolinieritas pada tabel di atas diperoleh nilai tolerance masing-masing variabel bebas yaitu rekruitmen sebesar 0,667 dan seleksi sebesar 0,667, dimana kedua nilai tersebut kurang dari 1, dan nilai Variance Inflation Factor (VIF) variabel rekruitmrn sebesar 1,499 serta seleksi sebesar 1,499 dimana nilai tersebut kurang dari 10. Dengan demikian model regresi ini tidak ada multikolinearitas. 


\section{Uji Autokorelasi}

Tabel 7. Uji Durbin-Watson

\begin{tabular}{|l|c|r|c|c|c|}
\hline \multicolumn{7}{|c|}{ Model Summaryb } \\
\hline Model & $\mathrm{R}$ & R Square & $\begin{array}{c}\text { Adjusted R } \\
\text { Square }\end{array}$ & $\begin{array}{c}\text { Std. Error of } \\
\text { the Estimate }\end{array}$ & $\begin{array}{c}\text { Durbin- } \\
\text { Watson }\end{array}$ \\
\hline 1 & $.535^{\mathrm{a}}$ & .286 & .256 & 2.74942 & 1.568 \\
\hline a. Predictors: (Constant), Rekruitmen (X2), Seleksi (X1) \\
\hline \multicolumn{7}{|l}{ b. Dependent Variable: Produktivitas (Y) } \\
\hline
\end{tabular}

Sumber : Data diolah (2020)

Berdasarkan hasil pengujian pada tabel di atas, model regresi ini tidak ada autokorelasi, hal ini dibuktikan dengan nilai Durbin-Watson sebesar 1.568 yang berada diantara interval $1.550-2.460$.

\section{Uji Heteroskedastisitas}

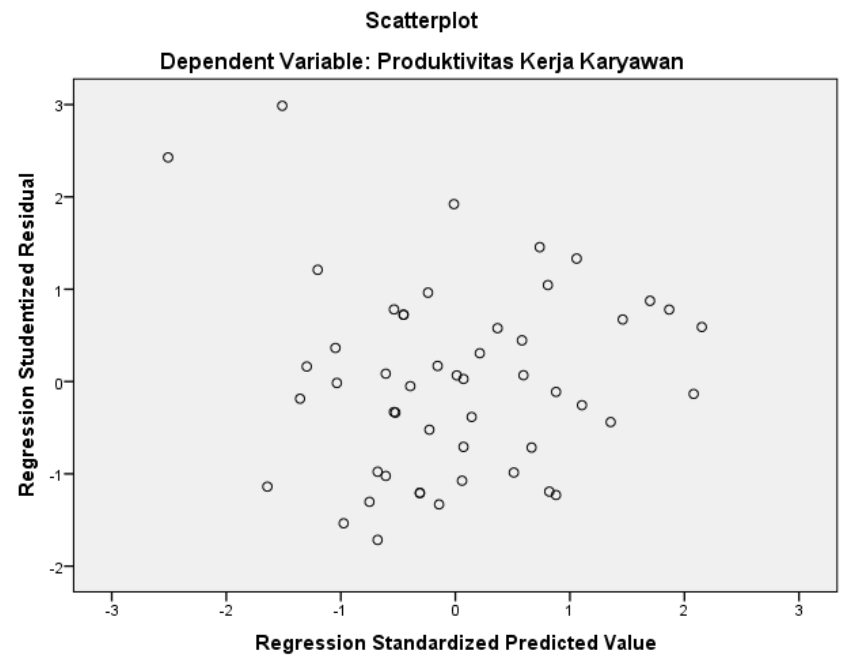

Sumber : data output yang diolah, 2020

\section{Gambar 1 Uji Heteroskedastisitas}

Pada gambar diatas, dapat bisa dilihat bahwa titik - titik pada grafik scatterplot tidak mempunyai pol ayang jelas dan penyebaran nya tidak teratur diatas dan dibawah angka 0 pada sumbu Y, maka dapat disimpulkan bahwa tidak terjadi maslah heteroskedastisitas.

\section{Analisis Kuantitatif}

Regresi Linier Berganda

Tabel 8. Hasil Pengujian Regresi Berganda Variabel Rekruitmen $\left(X_{1}\right)$ dan Seleksi $\left(\mathrm{X}_{2}\right)$ Terhadap Produktivitas $(\mathrm{Y})$

\begin{tabular}{|c|c|c|c|c|c|c|}
\hline \multicolumn{7}{|c|}{ Coefficients $^{\mathbf{a}}$} \\
\hline & \multirow[t]{2}{*}{ Model } & \multicolumn{2}{|c|}{$\begin{array}{l}\text { Unstandardized } \\
\text { Coefficients }\end{array}$} & \multirow{2}{*}{$\begin{array}{c}\begin{array}{c}\text { Standardized } \\
\text { Coefficients }\end{array} \\
\text { Beta }\end{array}$} & \multirow[t]{2}{*}{$\mathrm{t}$} & \multirow[t]{2}{*}{ Sig. } \\
\hline & & $\mathrm{B}$ & Std. Error & & & \\
\hline \multirow{3}{*}{1} & (Constant) & 21.041 & 4.362 & & 4.824 & .000 \\
\hline & Rekruitmen (X1) & .121 & .126 & .144 & .962 & .341 \\
\hline & Seleksi (X2) & .385 & .385 & .439 & 2.936 & .005 \\
\hline
\end{tabular}

Sumber : Data diolah (2020) 
Berdasarkan hasil analisis perhitungan regresi pada tabel di atas, maka dapat diperoleh persamaan regresi $\mathrm{Y}=21,041+0,121 \mathrm{X}_{1}+0,385 \mathrm{X}_{2}$. Dari persamaan di atas maka dapat disimpulkan sebagai berikut:

1. Nilai konstanta yaitu sebesar 21,041 yang menyatakan bahwa jika nilai dari variabel rekrutmen (x1) dan seleksi (x2) tidak ada atau bernilai $=0$ maka nilai dari variabel produktivitas kerja karyawan (Y) adalah 21,041.

2. Nilai dari koefisien regresi dari variabel rekrutmen (x1) adalah sebesar 0,121, maka dapat diartikan jika variabel bebas (independent) lain nilainya tetap dan seleksi mengalami kenaikan 1 poin maka produktivitas kerja karyawan nya juga ikut meningkat sebesar 0,121 satuan dan koefisien bernilai positif yang dimana artinya jika rekrutmen mengalami peningkatan maka produktivitas kerja karyawan juga akan ikut meningkat.

3. Nilai dari koefisien regresi dari variabel seleksi (x2) adalah 0,385, maka dapat diartikan jika variabel bebas (independent) lain nilainya tetap dan seleksi mengalami kenaikan 1 poin maka produktivitas kerja karyawan juga ikut meningkat sebesar 0,385 satuan dan koefisien bernilai positif yang artinya jika seleksi mengalami peningkatan maka produktivitas kerja karyawan juga akan ikut meningkat.

\section{Analisis Koefisien Korelasi (r)}

Tabel 9. Hasil Analisis Koefisien Korelasi Secara Simultan Antara Rekruitmen ( $\left.\mathrm{X}_{1}\right)$ dan Seleksi $\left(\mathrm{X}_{2}\right)$ Terhadap Produktivitas (Y)

\begin{tabular}{|l|c|c|c|c|}
\hline \multicolumn{5}{|c|}{ Model Summary } \\
\hline Model & $\mathrm{R}$ & R Square & $\begin{array}{c}\text { Adjusted R } \\
\text { Square }\end{array}$ & $\begin{array}{c}\text { Std. Error of the } \\
\text { Estimate }\end{array}$ \\
\hline 1 & $.535 \mathrm{a}$ & .286 & .256 & 2.74942 \\
\hline \multicolumn{4}{|l|}{ a. Predictors: (Constant), Seleksi (X2), Rekruitmen (X1) } \\
\hline
\end{tabular}

Sumber : Data diolah (2020)

Dari hasil output SPSS 23 yang dapat dilihat dari tabel diatas, maka hasil yang telah diperoleh untuk nilai kefisien korelasi antara variabel rekrutmen (X1) dan Seleksi (X2) terhadap produktivitas kerja karyawan $(\mathrm{Y})$ adalah sebesar 0,535. Oleh karena itu dapat disimpulkan bahwa variabel rekrutmen (x1) seleksi (X2) saling berhubungan kuat terhadap produktivitas kerja karyawan (Y) yaitu sebesar 53,5\% dan sisanya 46,5\% yang dipengaruhi oleh faktor dari luat variabel yang digunakan dalam penelitian saat ini.

\section{Analisis Koefisien Determinasi (R Square)}

Tabel 10. Hasil Analisis Koefisien Determinasi Secara Simultan Antara Variabel Rekruitmen ( $\left.\mathrm{X}_{1}\right)$ dan Seleksi $\left(\mathrm{X}_{2}\right)$ Terhadap Produktivitas $(\mathrm{Y})$

\begin{tabular}{|l|c|c|c|c|}
\hline \multicolumn{5}{|c|}{ Model Summary } \\
\hline Model & $\mathrm{R}$ & $\begin{array}{c}\mathrm{R} \\
\text { Square }\end{array}$ & $\begin{array}{c}\text { Adjusted R } \\
\text { Square }\end{array}$ & $\begin{array}{c}\text { Std. Error of the } \\
\text { Estimate }\end{array}$ \\
\hline 1 & $.504^{\mathrm{a}}$ & .254 & .223 & 2.827 \\
\hline \multicolumn{4}{|c|}{ a. Predictors: (Constant), Seleksi (X2), Rekruitmen (X1) } \\
\hline
\end{tabular}

Sumber : Data diolah (2020)

Berdasarkan pada hasil pengujian pada tabel di atas, didapatlah nilai $\mathrm{R}=0,504$ dan koefisien Determinasi (R square) sebesar 0,254. Hal ini menunjukan pengertian bahwa antara variabel rekrutmen (X1) dan seleksi (X2) terhadap produktivitas kerja karyawan (Y) mempunyai hubungan yang cukup kuat dengan nilai $\mathrm{R} 0,504$ dan kontribusi kedua variabel bebas R2 sebesar $25,4 \%$ sedangkan sisanya sebesar $74.6 \%$ dipengaruhi oleh variabel lain diluar variabel yang digunakan penelitian ini. 


\section{Pengujian Hipotesis}

Tabel 11. Hasil Uji Hipotesis (Uji t) Variabel Rekruitmen $\left(\mathrm{X}_{1}\right)$ dan Seleksi $\left(\mathrm{X}_{2}\right)$ Terhadap Produktivita (Y)

\begin{tabular}{|c|c|c|c|c|c|c|}
\hline \multicolumn{7}{|c|}{ Coefficients $^{a}$} \\
\hline & \multirow[t]{2}{*}{ Model } & \multicolumn{2}{|c|}{$\begin{array}{l}\text { Unstandardized } \\
\text { Coefficients }\end{array}$} & \multirow{2}{*}{$\begin{array}{c}\begin{array}{c}\text { Standardized } \\
\text { Coefficients }\end{array} \\
\text { Beta }\end{array}$} & \multirow[t]{2}{*}{$\mathrm{t}$} & \multirow[t]{2}{*}{ Sig. } \\
\hline & & $\mathrm{B}$ & Std. Error & & & \\
\hline \multirow{3}{*}{1} & (Constant) & 22.009 & 4.485 & & 4.908 & .000 \\
\hline & Rekruitmen (X1) & .103 & .130 & .121 & .794 & .431 \\
\hline & Seleksi (X2) & .375 & .135 & .424 & 2.779 & .008 \\
\hline
\end{tabular}

Sumber : Data diolah (2020)

Berdasarkan tabel diatas dapat dilihat hasil output data yang telah diolah, dapat dijelaskan tentang pengaruh variabel independen terhadap variabel dependen seperti berikut ini :

1. Pengaruh rekrutmen (x1) terhadap produktivitas kerja karyawan (y) : Berdasarkan output SPSS diatas diketahui nilai thitung variabel rekrutmen adalah sebesar 0,794. Kareana nilai thitung $0,794<$ ttabel 1,677, maka dapat disimpulkan bahwa $\mathrm{H} 1$ atau hipotesis pertama ditolak atau tidak ada pengaruh rekrutmen (x1) dan produktivitas kerja karyawan (y).

2. Pengaruh Seleksi (x2) terhadap produktivitas kerja karyawan (y) : Berdasarkan tabel output SPSS diatas diketahui nilai thitung variabel seleksi (x2) adalah sebesar 2,779. Karena thitung 2,779 > ttabel 1,677. Maka dapat disimpulkan bahwa $\mathrm{H} 2$ atau hipotesis kedua diterima atau adanya pengaruh seleksi $\left(\mathrm{X}_{2}\right)$ terhadap produktivtias kerja karyawan (y).

\begin{tabular}{|c|c|c|c|c|c|c|}
\hline \multicolumn{7}{|c|}{ ANOVA } \\
\hline & Model & $\begin{array}{l}\text { Sum of } \\
\text { Squares }\end{array}$ & $\mathrm{df}$ & $\begin{array}{c}\text { Mean } \\
\text { Square }\end{array}$ & $\mathrm{F}$ & Sig. \\
\hline \multirow{3}{*}{1} & Regression & 130.593 & 2 & 65.297 & 8.171 & $.001^{\mathrm{b}}$ \\
\hline & Residual & 383.564 & 48 & 7.991 & & \\
\hline & Total & 514.157 & 50 & & & \\
\hline \multicolumn{7}{|c|}{ a. Dependent Variable: Produktivitas (Y) } \\
\hline \multicolumn{7}{|c|}{ b. Predictors: (Constant), Seleksi (X2), Rekruitmen (X1) } \\
\hline
\end{tabular}

Berdasarakan tabel output SPSS di atas, diketahui nilai Fhitung adalah sebesar 8,171. Karena nilai Fhitung 8,171 > Ftabel 3,19, maka sebagaimana dasar pengambilan keputusan dalam uji F dapat disimpulkan bahwa hipotesis diterima atau dengan kata lain rekrutmen (x1) dan seleksi (x2) secara simultan berpengaruh terhadap produktivitas kerja karyawan (y).

\section{Kesimpulan}

Berdasarkan hasil dan nilai dari penelitian diatas yang telah dijelaskan atau diuraikan sebelumnya yang mana menunjukan hasil adanya pengaruh positif dan signifikan baik secara parsial maupun simultan dari variabel rekrutmen dan seleksi terhadapa produktivitas kerja karyawan. Dengan itu maka selanjutnya akan diuraikan tentang pembahasan terkait hasil dari temuan - temuan yang terdapat dalam penelitian ini, berikut adalah uraian nya :

1. Pengaruh Rekrutmen (x1) terhadap Produktivitas Kerja Karyawan (Y) : Dari hasil atau nilai penelitian yang telah dilakukan sebelumnya diketahui terdapat adanya pengaruh negatif antara rekrutmen (x1) terhadap produktivitas kerja karyawan (y). yang diantaranya rekrutmen (x1) terhadap produktivitas kerja karyawan (y) mendapatkan nilai Thitung sebesar 0,794 dan Ttabel dengan tingkat signifikansi 0,05 / 5\% untuk (df) 48 
yaitu sebesar 1,677. Dengan begitu dapat dikatakan bahwa thitung $<$ ttabel $(0,794<$ ttabel $1,677)$ dan signifikansi $>0,05(0,431>0,05)$. Dengan demikian dapat disimpulkan bahwa rekrutmen secara parsial tidak berpengaruh positif dan tidak signifikan terhadap produktivitas kerja karyawan pada Yayasan Pondok Indah Don Bosco.

2. Pengaruh Seleksi (x2) terhadap Produktivitas Kerja Karyawan (y) : Dari hasil atau nilai penelitian yang telah dilakukan sebelumnya diketahui terdapat adanya pengaruh positif antara seleksi (x2) terhadap produktivitas kerja karyawan (y). yang diantaranya seleksi (x2) terhadap produktivitas kerja karyawan (y) mendapatkan nilai Thitung sebesar 2,779 dan Ttabel dengan tingkat signifikansi 0,05 / 5\% untuk (df) 48 yaitu 1,677. Dengan begitu dapat dikatakan bahwa thitung $>$ ttabel $(2,779>1,677)$ dan signifikansi $<0,05(0,008<$ $0,05)$. Dengan demikian dapat disimpulkan bahwa seleksi secara parsial berpengaruh positif dan signifikan terhadap produktivitas kerja karyawan pada Yayasan Pondok Indah Don Bosco.

3. Pengaruh Rekrutmen (X1) dan Seleksi (X2) terhadap Produktivitas Kerja Karyawan (Y) : Dari hasil dan nilai penelitian sebelumnya yang telah dilakukan dapat diketahui adanya pengaruh positif antara rekrutmen dan seleksi terhadap produktivitas kerja karyawan. Hal ini telah membuktikan bahwa dengan yang didapatkan dari hasil uji hipotesis pengaruh rekrutmen (x1) dan seleksi (x2) terhadap produktivitas kerja karyawan (y) telah memperoleh 8,171 dan sig. yaitu 0,001. Maka Fhitung > Ftabel karena 8,171 > 3,19, kemudian sig $<\alpha=0,05$ karena 0,001 $<0,05$, maka dapat diambil kesimpulan bahwa rekrutmen dan seleksi secara simultan berpengaruh positif dan signifikan terhadap produktivitas kerja karyawan pada Yayasan Pondok Indah Don Bosco.

\section{Daftar Pustaka}

Ading, S. (2020). PENGARUH GAYA KEPEMIMPINAN, MOTIVASI, SERTA DISIPLIN KERJA TERHADAP KINERJA KARYAWAN (Study di PT Mitsui Leasing Capital Indonesia Abdul Muis-Jakarta Pusat). KREATIF: Jurnal Ilmiah Prodi Manajemen Universitas Pamulang, 8(1), 18-38.

Marwansyah. (2014). Manajemen Sumber Daya Manusia. Jurnal Ekonomi Unpam. 128.

Santoso, S. (2015). SPSS20 Pengolahan Data Statistik di Era Informasi, Jakarta, PT. Alex Media Komputindo, Kelompok Gramedia.

Simamora. (2014). Membuat Karyawan Lebih Produktif Dalam Jangka Panjang. Jurnal Ekonomi Unpam. 170.

Sondang, P. Siagian. (2012). Manajemen Sumber Daya Manusia. Jurnal Ekonomi Unpam. 15. . (2014). Manajemen Sumber Daya Manusia Jurnal Ekonomi Unpam. 131.

(2015). Manajemen Sumber Daya Manusia. Jurnal Ekonomi Unpam. 102. .

Sugiyono. (2012). Metode Penelitian Kuantitatif Kualitatif Dan R\&D. Bandung: PT. Alfabet.

Sunarto, A., Qurbani, D., \& Virby, S. (2020). Pengaruh Kompetensi, Disiplin Kerja Dan Lingkungan Kerja Terhadap Kinerja Pada PT Anugrah Bersama Sejahtera Depok. JIMF (Jurnal Ilmiah Manajemen Forkamma), 4(1).

Sunarto, A., Tanjung, A. W., \& Ellesia, N. (2020). Teacher Performance Based on The Visionary Leadership Style of School, Competency and Work Discipline (Study at Muhammadiyah Setiabudi Pamulang College).Journal of Research in Business, Economics, and Education, 2(5), 1046-1052. 
Sunarto, A. (2020). Kinerja Karyawan Berbasis Kepemimpinan Dan Motivasi Pada PT. Duta Jaya Putra Persada Mining.JENIUS (Jurnal Ilmiah Manajemen Sumber Daya Manusia), 3(3), 246-257. 